\title{
THE POLITICAL ECONOMY OF INDIA'S ECONOMIC CHANGES SINCE THE LAST CENTURY
}

\begin{abstract}
The objective of this study is to examine India's transformation from a colonial to a modern economy on the basis of the macro-economic changes that have occurred over the last century. This is important because it will help us to understand the associated growth performance and its impact on sectoral changes and employment in the wider context of developing economies such as India. The methodology to be followed here is derived from the aims of the study and comparisons of international statistics that provide the means by which to address the research questions and the objectives of this paper. The study found that during the colonial period, the Indian economy became subservient rather than sovereign in terms of policy matters. As a result, economic development was hampered by the removal of "surplus", along with very high land rents and tribute charges. A densely populated country like India was drawn into the orbit of exploitation in the mid-18th century. Soon after independence in 1947, the Indian government took a number of initiatives to enhance industrial and agricultural development, but the biggest failure was that it did not make any real impression on the country's huge unemployment problems.
\end{abstract}

Keywords: Indian economy, colonial period, famines, growth rates and neoliberal reforms.

JEL Classification: O1, O5, N0, N5.

Kalim Siddiqui, University of Huddersfield, The Business School, Department of Accounting, Finance and Economics, Queensgate, Huddersfield - HD1 3DH, UK, e-mail: k.u.siddiqui@ hud.ac.uk

The author would like to thank John Smith and Barry Pavier for helpful comments on an earlier draft of the paper and for helpful ideas and suggestions and also would like to thank two anonymous reviewers for their suggestions. The author is solely responsible for the views expressed in this paper. 


\section{Introduction}

The aim of this paper is to analyse economic policy and its performance in India during the past century. In doing so, the article examines the limitations of such policies. This study is important because India is the second-largest populated country in the world, now having almost same population as China, and also the study of a longer period of economic changes and polices provides us with a better understanding of the past and present. A critical examination of the Indian economy, besides India, can also help other developing countries to draw lessons from its strengths and weaknesses.

The methodology to be followed here is derived from the aims of the study and comparisons of international statistics that provide the means by which to address the research questions and the objectives of this paper. Analysing pre-existing secondary data is the only possible way to obtain macroeconomic data. These include data from official sources and from international institutions such as the IMF (International Monetary Fund), World Bank and OECD. Due to the nature of the topic, it is considered that such methods will be appropriate to undertake this study.

The objective of this study is to examine India's transformation from a colonial to a modern economy on the basis of the macro-economic changes that have occurred over the last century. This is important because it will help us to understand the associated growth performance and its impact on sectoral changes and employment in the wider context of developing economies such as India.

In recent years, India has experienced remarkably high economic growth rates, which have led to much speculation in the media that India is an emerging economic superpower. However, such discussions have overlooked the fact that this growth has not been accompanied by an associated rise in equality or reduction in social ethnic conflict. Yet despite all the failings and mistakes, the record of Indian government since the country became independent (about 70 years ago) in most respects has shown vastly better growth and performance than under the previous British colonial rule, especially on such indices as GDP growth rates, living conditions, health, literacy rates, life expectancy and overcoming famine and mass hunger (Siddiqui 2015).

We need to look at basic facts about India's experience with British colonialism and why colonial (mis) rule cannot be put aside. The study also intends to examine the legacy of the British Raj and also post-colonial 
development, and also that later failures do not in any sense invalidate my criticism of colonial exploitation and subjugation. British economic historian Angus Maddison (2003) calculated that India's share of the world economy was a quarter of the world's GDP in the mid-18th century, larger than that of all European countries combined at that time. In fact, in 1705, this figure was as high as $27 \%$ when Mughal Emperor Aurangzeb ruled the country. By the time the British departed India, GDP share had dropped to 3\% (Tharoor 2017). The reason was that India was ruled to benefit Britain and, as a colony for two hundred years, India was financing not only the industrialisation of Britain but also its military ventures in Asia, East Africa and the Middle East (Bagchi 2010).

This article is organised as follows. Following the introduction to this topic in Section 1, Section 2 will briefly discuss the colonial legacy. Section 3 analyses the economic policies and performance of the post-independent period, in particular from 1947 to 1990, whilst Section 4 examines the period of neoliberal economic reforms, i.e., from 1991 to date, followed by a conclusion which summarises the findings.

At independence in 1947, modern large-scale industries and mining constituted just 7\% of India's GDP, while small-scale industries accounted for $10 \%$, the agricultural sector, $49 \%$, and services and construction, $34 \%$. Total employment in the industrial sector was just 2.9 million people, which amounted to less than $2 \%$ of the total workforce. In contrast to this, small industries employed a much higher proportion, some $7 \%$ of the workforce, while nearly $72 \%$ of the Indian workforce was employed in agriculture; services including construction employed $18.7 \%$. Cotton and jute were among the main modern industries established in the early 20th century in India (Siddiqui 1996).

The tasks for independent India in 1947 were to accelerate the transition towards a modern economy, as dominated by industry. This was because on the eve of independence, the agricultural sector accounted for half of the country's GDP and modern industry contributed only $7 \%$ of the total GDP. In fact, despite the development of a few industries during colonial rule, India was still predominantly an agrarian country with low productivity that suffered from widespread poverty and illiteracy. During the 1950s, the government took a number of measures in industrial and agricultural sectors through public investment in accord with its plans to establish several heavy and capital-intensive industries in crucial areas such as steel, machines and tools, power generation, and in irrigation and technical and scientific institutions such as the Indian Institute of Technology. As a result, in the 
1950s growth rates rose to be higher than in previous decades, but still lower than those of other East Asian economies (Siddiqui 2016a). The most important issue was that this growth left unemployment and poverty largely unaffected. Moreover, by the late 1960s, the economy began to slow, heralding the start of a crisis that subsequently became more severe in the late 1970 s and in the early 1980s where in order to fund populist measures the government resorted to heavy foreign loans. This seemed, and indeed was, to represent only short-terms relief for the country, and the situation became more critical in the 1990s (Siddiqui 2018).

World oil prices rose in response to the Iraqi invasion of Kuwait in 1990 and, as a result, India's import bills increased sharply; so, when the Soviet Union collapsed in 1991, India experienced a balance of payments crisis. During that time, the then Finance Minister Manmohan Singh stated in his budget speech: "There is no time to lose. Neither the government nor the economy can live beyond its means year after year. The room for manoeuvre, to live on borrowed money or time, does not exist anymore. Any further postponement of macro-economic adjustment, long overdue, would mean that the balance of payments situation, now exceedingly difficult, would become unmanageable and inflation, already high, would exceed limits of tolerance" (Ministry of Finance 1991-92).

India asked for an IMF loan in 1991 and, in return, the country was asked to implement neoliberal reforms also known as 'Structural Adjustment Programmes' (Siddiqui 2012). The mainstream economists welcomed this and emphasised that these reforms would increase competition and efficiency. According to them, any distortions were associated with government intervention and regulation of markets and the crucial issue of aggregate employment determination. Any distortions induced by the government involving the use of monetary and fiscal policy to raise employment would merely generate inflation. They maintained that economic development requires rapid GDP growth, which has a "trickle-down effect", ultimately benefitting the poor (World Bank 2016).

\section{India's Colonial Legacies}

It is widely recognised that, until 1760 , India was the second-largest manufacturing economy after China. India exported cotton textiles to Africa, Europe and South East Asia (Bagchi 2010). As J. T. Sunderland (1929, p. 367), a British-born and US minister, noted, "India was a far greater industrial and manufacturing nation than any in Europe or any other 
in Asia. Her textile goods - the fine products of her looms, in cotton, wool, linen and silk - were famous over the civilized world; so were her exquisite jewellery and her precious stones (...); so were her fine works in metal-iron, steel, silver and gold (...). [India] had great architecture (...) great businessmen, great bankers and financiers. Not only was she the greatest shipbuilding nation, but she had a great commerce and trade by land and sea which extended to all known civilized countries. Such was the India which the British found when they came".

However, in 1757, Robert Clive defeated Nawab Siraj-ud-Duala and Bengal was taken over by the (British) East India Company; at the time, Bengal was the richest province of India. However, after the British imposed colonial rule Bengal in 1757, and especially after the end of the Napoleonic Wars, India's textile industries were systematically destroyed, large urban centres known for textile industries were depopulated, and as a result the proportion of people dependent on agriculture rose dramatically. The textile industries in Manchester were protected, while "free trade" was forced on India. As a result, Indian-made cloths paid higher duties than cloths imported from Manchester. This, of course, had very serious implications for Indian handicraft industries and for social structure and the structure of the rural economy as a whole (Siddiqui 1990).

India dominated in global textile trade until 1760, but with the onset of colonialism this no longer remained the case. Britain imposed tariffs and duties of $70 \%$ to $80 \%$ on Indian textiles exported to Britain, making their sale unviable for Indian exporters. This made Indian textiles expensive in the British markets, while India could not impose retaliatory tariffs on British goods since the British controlled the ports and the government (Tharoor 2017). Under colonialism, Indian manufactures did not receive any assistance from the government, despite lower wages and locally produced raw materials of which the domestic manufacturers could not take advantage. India still grew cotton as a raw material that was exported to Britain. The devastation of textiles' deindustrialisation and the devastation of the textile industry as a whole significantly reduced the urban population, which is also known as de-urbanisation. As the number of people subsequently dependent on agriculture rose sharply, such development drove rural wages down. Of course, there were some good periods too. For example, the American Civil War interrupted supplies of raw cotton from the New World. This resulted in a boom for Indian cotton growers, but once American supplies were resumed in 1865, they suffered again (Siddiqui 1990). 
In a very short period, India moved from being an exporter of high-quality finished goods to a mere exporter of raw materials such as cotton, jute, opium, spices, tea and rice. The huge increase in the cultivation of opium, indigo, tea and jute led to the decline of land available for the cultivation of food crops. Between 1770 and 1800, India's share in world manufacturing exports fell from $27 \%$ to $2 \%$, while exports from Britain to India rose sharply under the duty-free and free trade regime imposed by colonialism (Bagchi 2010).

In the agricultural sector, the British created layers of intermediaries between actual cultivators and the landlords who paid land rent directly to the colonial administration. Land rent increased sharply as compared to the pre-colonial period, and during poor monsoon and famine, rents were not reduced, which led to increased reliance on money lenders who exploited the peasants with their high usurious rates of interest, thus keeping borrowers in a position of virtual bondage (Bagchi 2010).

In contrast to the Mughal period, under the British land revenue system, if a farmer's crop failed he was not exempted from paying taxes. The British revenue system was based on potential rather than actual output. The land taxes were not returned in the form of public goods or services, but were rather sent to the British government in London. The lack of investment either from public or private sources destroyed Indian agriculture. As Sir George Wingate notes, "Taxes spent in the country from which they are raised are totally different in their effect from taxes raised in one country and spent in another. In the former case the taxes collected from the population (...) are again returned to the industrious classes (...) But the case is wholly different when the taxes are not spent in the country from which they are raised (...). They constitute [an] absolute loss and extinction of the whole amount withdrawn from the taxed country (...). [The money] might as well be thrown into the sea. Such is the nature of the tribute we have long extracted from India" (cited in Tharoor 2017, p. 26).

F. J. Shore, who worked as British administrator in Bengal, testified before the House of Commons in 1857: "The fundamental principle of the English has been to make the whole Indian nation subservient, in every possible way, to the interest and benefits of themselves. They have been taxed to the utmost limit; every successive province, as it has fallen into our possession, has been made a field for higher extraction; and it has always been our boast how greatly we have raised the revenue above that which the native rulers were able to extort" (cited in Tharoor 2017, p. 16). 
In the 18th and 19th centuries under Britain, opium was produced in India and exported to China. The British used the profits from the sale of opium to pay for imports from China such as tea, silk and porcelain, which were in great demand in Europe, while there was no demand in the Chinese markets for European-manufactured goods. Consequently, European traders had to pay for Chinese products with gold and silver. The (British) East India Company established a monopoly on opium cultivation in the Indian province of Bengal, where they forced peasants to grow opium poppies. The opium trade solved this chronic trade imbalance. The efforts of the Qing dynasty to enforce the opium restrictions led to two armed conflicts between China and Britain, known as the Opium Wars, i.e., the first opium war (1839-42) and the second war (1856-60), when British and French troops attacked, and forced China to legalise the opium trade (Bagchi 2010).

As Tharoor (2017, p. 5) finds: "Britain's industrial revolution was built on the destruction of India's thriving manufacturing industries. Textiles were an emblematic case in point: the British systematically set about destroying India's textile manufacturing and exports, substituting Indian textiles by British ones manufactured in England. Ironically, the British used Indian raw material and exported the finished products back to India and rest of the world". Tharoor (2017, pp. 5-6) further notes: "The British destruction of textile competition from India led to the first great deindustrialisation of the modern world. Indian handloom fabrics were much in demand in England; (...) For centuries the handloom weavers of Bengal had produced some of the world's most desirable fabrics, especially the fine muslins, light as 'woven air', that were coveted by European dressmakers. As late as the mid-eighteenth century, Bengal textiles were still being exported to Egypt, Turkey and Persia in the West, and to Java, China in the East, along well-established trade routes, as well as to Europe".

On top of this, Paul Baran calculated that about $8 \%$ of the India's GNP was transferred annually to Britain as "Home Charges" (Tharoor 2017). Naoroji's book Poverty and Un-British Rule in India, which was published in 1892, presented the "drain theory". According to Naoroji, this transfer of surplus was the main cause of poverty in India (Bagchi 2010). Another study by British economic historian Angus Maddison concluded: "There can be no denial that there was a substantial outflow which lasted for 190 years. If these funds had been invested in India, they could have made a significant contribution to raising income levels" (cited in Tharoor 2017, p. 22). On top of this, thousands of British officials, who worked in India and received 
inflated wages and pensions and remittances, were another big drain on resources.

However, recently, apologists for imperialism such as Niall Ferguson and others have denied that the possession of colonies benefitted Britain or that it contributed to the destruction of the Indian economy and society in any way. This is the reason that it is important to briefly examine the economic and social consequences of colonial rule in India. Bagchi (2010, p. XXII) notes: "[in] the years between 1896 and 1913, [Britain superimposed a] long-term downward trend in income and living standards (...) hundreds of thousands of artisans lost their livelihoods, productivity-increasing investment in agriculture shrank, and business communities in many parts of colonial India were pushed out of the most profitable avenues of trade or became subordinate collaborators of European businessmen. India witnessed some of the biggest famines in history, in Bengal from 1769, in south India from the 1780 s down to the 1830 s, again between the 1870 s and early 1900s in western and southern India, apart from many smaller famines that were not officially recognised". Many artisans became tenants or agricultural labourers or simply starved to death during these famines. Moreover, the colonial government was insensitive to the deaths of tens of millions of Indians during such periods, including several hundred million alone due to avoidable malnutrition and poverty-related diseases (Sen 1981).

After Britain colonised Bengal, the surplus extracted helped Britain in its military success against France. As Bagchi (2010, p. XXVI) emphasised: "the tribute extracted from India played a critical part in sustaining the British war against the French, and in facilitating the building up of the overseas settlements of Europeans through the process of European migration and British foreign investment from the 1870s to the First World War. Moreover, the migration of indentured labourers to European-controlled plantations stretching from the Caribbean to Malaysia provided sugar, tea, and other plantation products much needed by the global capitalist economy. Thus, Indian history is a critical part of global history as, indeed, global history is a part of Indian history".

Indian nationalists such as D. Naoroji, M. G. Ranade, R. C. Dutt, Mahatma Gandhi and Nehru were highly critical of the economic policy pursued by the British colonial administration in India. These policies were "free trade" and the role of the state was only limited to constructing ports, railways and roads to facilitate the transport of raw materials from interior regions to port and return British-manufactured goods to the Indian markets. Despite certain modifications after World War I, most of 
the profitable industries, for instance mining and plantations, were still controlled by British businesses. The Indian nationalists believed that state intervention in the economy could help to build basic industries. Unlike imperialist historians such as Vera Anstey, who blamed Indian culture for the country's backwardness and mass poverty in the country (Siddiqui 1996), nationalists, on the other hand, pointed to the transfer of the annual tribute to the British rulers, and also the further drain of resources to finance British military ventures from Kabul (Anglo-Afghan War from 1839 to 1842), Burma, Malaysia, Egypt, Sudan and Mesopotamia in the 1860s. The British Indian Army was not only maintaining India's security, but was also sent on foreign colonial expeditions to fight for British imperial interests. In 1922, for example, $64 \%$ of the total revenue of the government of India was spent on paying for British Indian troops despatched overseas (Bagchi 2010).

A major characteristic of colonial rule in India was the destruction of indigenous industries, and the failure to replace them with modern industries accentuated the situation in India. On the top of this, problems were compounded by high taxes, the drain of wealth and negligible growth in agricultural productivity, and the exploitation of the peasantry by landlords and money lenders, reducing the rural population to extreme poverty. This resulted in widespread famine in India, beginning in 1770 with the Bengal famine, which is estimated to have killed one-third of the entire Bengali population (i.e. around 10 million). With regard to the total number of deaths in major famines in India, British writer William Digby calculated that nearly 29 million had died between 1854 and 1901 alone (Sen 1981). Bagchi (2010, p. XXVI) concluded that: "The process of colonisation of the Indian economy involved the extraction of a tribute from the economy at an unprecedented rate. That extraction, in turn, required the structural adjustment of the economy in the sense that the domestic absorption of the commodities produced by India had to be continually squeezed so as to yield an exportable surplus that would be remitted to the ruling country (...). Deindustrialisation in India was accompanied not by reallocation of normally growing resources to agriculture but depression of growth rates in both industry and agriculture".

In fact, through the control and subjugation of former colonial countries (i.e. the periphery), the "core" had established the practice of setting the prices not only of primary commodities such as oil and minerals, but also tropical agricultural commodities which could not be produced in the temperate regions of the "core" countries. The rise in demand for certain 
tropical agricultural commodities was not accompanied by an increase in their prices, however. As Patnaik (2014, p. 3) argues: "The fact that this did not happen, and has not happened to date, needs to be examined. And this explanation lies in the fact that capitalism imposes an 'income deflation' on the people of the 'outlaying regions', which restricts, even reduces, their purchasing power and hence their demand either for these goods directly, or for other goods which are their substitutes in the sense of being producible on the same land mass (...). 'Income deflation' thus ensures that the increasing amounts of goods demanded at the 'core', but produced on the tropical land mass, are made available to it without any increase in their prices, even though tropical agriculture as a whole remains stagnant".

Table 1. China and India in the World Economy and World Population, 1705-1950 (\%)

\begin{tabular}{l|c|c|c|c|c}
\hline \multirow{2}{*}{\multicolumn{1}{c}{ Specification }} & \multicolumn{5}{c}{ Share in World GDP in 1990 (Geary-Khamis PPP), } \\
\cline { 2 - 6 } & 1700 & 1820 & 1870 & 1913 & 1950 \\
\hline China & 23.6 & 33.0 & 17.1 & 8.8 & 4.6 \\
\hline India & 27.0 & 16.1 & 12.2 & 7.5 & 4.2 \\
\hline Developing Countries & 71.1 & 63.0 & 42.1 & 29.6 & 27.0 \\
\hline Western Europe & 21.3 & 22.9 & 32.6 & 34.1 & 26.2 \\
\hline World & 100.0 & 100.0 & 100.0 & 100.0 & 100.0 \\
\hline & Proportion of the World Population \\
\hline China & 33.0 & 36.3 & 28.1 & 24.4 & 21.26 \\
\hline India & 21.6 & 20.1 & 19.8 & 16.9 & 14.2 \\
\hline Developing Countries & 76.2 & 74.4 & 67.8 & 63.2 & 67.0 \\
\hline Western Europe & 13.2 & 12.8 & 14.2 & 14.9 & 12.1 \\
\hline World & 100.0 & 100.0 & 100.0 & 100.0 & 100.0 \\
\hline
\end{tabular}

Source: Maddison (2003), Bagchi (2010), Tharoor (2017).

As Table 1 indicates, in 1700 India was the largest economy in the world, and its GDP share alone was $27 \%$. However, a few decades after colonisation, India's share of global GDP had declined to $16.1 \%$ in $1820,7.5 \%$ in 1913, and was only $4.2 \%$ in 1950 . China's share of global GDP declined also, especially in the aftermath of the second opium war, i.e., $33 \%$ in 1820 to $17.1 \%$ in 1870 , and continued to decline to $4.6 \%$ in 1950 (see Table 1).

India was one of the richest and most industrialised economies of the world, which together with China accounted for about $75 \%$ of the world's 
industrial output in 1750. In 1600, when the (British) East India Company was first established, Britain was producing only $1.8 \%$ of the world's GDP, while India's share was 27\%. By 1950, after two hundred years of British rule, Britain accounted for $4.2 \%$ of the world's GDP, while India had been reduced to mass poverty, illiteracy and hunger. Moreover, between 1900 and 1947, India's average annual GDP growth was $0.9 \%$, while the population was growing at over 3.5\% (Siddiqui 1996), which was only negated by the high levels of infant and child mortality that reduced population growth to zero and life expectancy to only 27 years. Figure 1 presents the per capita economic growth of India between 1920 and 2015. The figure clearly shows that per capita income did not undergo any increase during the period between 1820 and 1950. However, after gaining independence in 1947, per capita income rose steadily, as indicated in Figure 1.

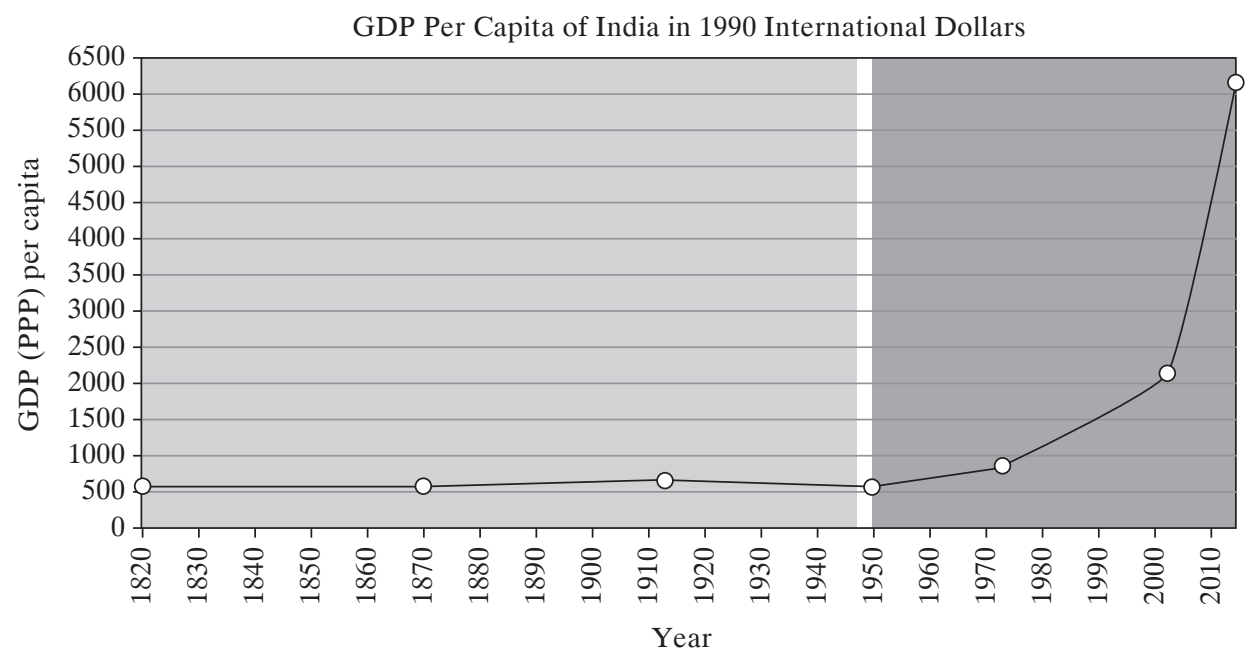

Period: $\square$ British rule $\square$ Republic of India

Fig. 1. India's Per Capita GDP from 1820 to 2015

Source: Tables of Angus Maddison (2003). The per capita GDP over various years and estimate is retrieved from the IMF (2017) and OECD (2017) (accessed: 5 June 2017).

On social issues such as the Hindu caste system, colonial rule did not make much difference. Caste is a reality in Indian society and is the predominant social identity in the villages. The castes also reinforce relations of dominance and dependence in rural India. Indian society has been marked historically by a level of institutional inequality due to the Hindu caste system, which includes even "untouchability" against 
the "lower castes". Despite the inclusion of judicial equality, the colonial administration did not take any concrete measure to undermine this caste social inequality. As Patnaik (2016, p. 5) notes: "there was formal equality before the law for everybody under colonialism, but this hardly had any impact in weakening caste discrimination at the ground level (...) the absence of alternative opportunities to the most menial and degrading occupation, and [these 'untouchables'] were even prevented over large parts of the country from owning any land. What is more, the 'lower castes' were among the worst victims of the economic exploitation of the country under colonial rule, through the twin processes of 'drain of surplus' (which meant a transfer without any quid pro quo of resources to the metropolis) and 'deindustrialisation' (which meant the destruction of local craft production by the import of machine-made manufactured goods from metropolis). The burden of this exploitation greatly increased the pressure of population on land through a process of pauperisation of the peasantry, and this growing pressure entailed a lowering of real wages of agricultural labourers, among whom, of course, the 'lower castes' had an overwhelming presence".

\section{Economic Performance from 1947 to 1990}

After independence, India's first Prime Minister, Jawaharlal Nehru, recognised that without the economic diversification and expansion of Indian industries, the aims of modernisation would not be accomplished. $\mathrm{He}$ believed that science and technology held the key to India's development and thus the consequent elimination of backwardness and poverty. It was hoped that such policies would increase productivity and generate employment, the latter required to absorb India's large number of unemployed and address the poverty and deprivation colonial rule left behind. The Second Five Year Plan was launched in 1956 with the target of increasing investment in key industries, power and infrastructure.

An "inward-looking" dirigiste economic strategy was adopted in India from the 1950s onwards, which was seen as the most suitable option by the ruling elites. Also known as the "import substitution" strategy, under this strategy the public sector was assigned a leading role in the development process. Between 1951 and 1965, annual average industrial growth was $7 \%$, which was much higher than anything that had been seen in the past. There was also a notable shift as the importance of traditional industries such as jute and cotton declined, while modern industries such as machinery, engineering, chemicals, rubber, pharmaceuticals, power and 
steel became more important. However, industrial growth also coincided with huge increments in foreign debts and foreign aid, which meant that industrialisation in India did not allow for financial self-reliance. Moreover, Indian industries did not allocate much money for research and development, which resulted in increased reliance on imported technology and foreign multinational corporations. Although pre-reform industrialisation in India was impressive in terms of its growth, it failed to make any real impression on growing unemployment (Siddiqui 2014a).

However, such policies were criticised by the neoclassical economists as inefficient, promoting delays and corruption. The proponents of neoliberal reforms argue that rather than adopting the classic Asian strategy - exporting labour-intensive low-priced manufactured goods to the West - India has relied on its domestic market more than exports, and consumption more than investment. In fact, the then government aimed to remove serious gaps in the production structure. Due to the long gestation period, private investors saw such investments as high risk, and also lacked the funds to support them. In fact, the government was determined not to tax the rich. Therefore, for public sector investment funding, the government relied on foreign aid, deficit financing and indirect taxation. As a result, for example, the share of indirect taxes in total tax revenue increased from $61.9 \%$ in 1955 to $70.7 \%$ in 1966 (Siddiqui 2015). Both indirect taxes and deficit financing were regressive, meaning that they had a dampening effect on income for the majority of people. As a result, the domestic market for mass consumer goods did not increase.

Regarding the agricultural sector, from which nearly three-quarters of India's population received its income, in the 1950s the Indian government passed legislation to implement land reforms, including the removal of rent-seeking absentee landlords. But these modest reforms were met with opposition from the government's own ministers and administrators, and further agrarian reforms in the 1950s failed to make any real impression on rural inequality. As a result, the reforms failed in removing the agrarian constraints, both in terms of the hurdle to the expansion of the domestic market and also in their inability to end the landlords' domination in rural areas. As Das Gupta notes: "This has four dimensions: first, it defined the demand constraint in the country and perpetuated the huge labour reserves inherited from the colonial period. Second, it ruled out a classical capitalist transformation in ruling out a process of development through creation and channelling of an agrarian surplus into industry. Third, it perpetuated one of the strongest links in preserving the links between caste, gender, and 
property relations in the hierarchy of definition of property rights. Fourth, it ensured the perpetuation of labour regimes based on extra-economic coercion" (Das Gupta 2016, p. 123).

However, post-independent agrarian reform - though not fully implemented and uneven in its depth from state to state - did manage to restrict, though not remove, rent-based landlordism and encourage rural capitalism. The land reform measures in the 1950s, while benefitting some tenants, failed to break land concentration and the top $15 \%$ of landowners continued to hold the same percentage of land as before the measures were undertaken (Siddiqui 1999). Rural inequality persisted, which had obvious socio-economic implications as it restricted the domestic market, including demand for manufacturing goods. On the social front, few changes were witnessed: landlords' oppressive Hindu caste system remained largely intact and untouchables (also known as Dalits), who constituted the core of the landless class and were denied land ownership under the old Hindu caste system, remained landless (Siddiqui 2014b).

In the mid-1960s, the rising prices and balance of payments crisis became unmanageable, leading to the devaluation of the rupee and forcing India to seek a loan from the IMF. Moreover, in the late 1960s, the adoption of HYV (High Yielding Varieties) seeds in certain crops, also known as the Green Revolution, raised agricultural output if HYV seeds were applied in the correct proportion with water, fertilisers and pesticides. Initially it encouraged large landholders towards direct cultivation as additional investment was assured to bring in higher profits due to the availability of subsidised credit, irrigation, and fertilisers. Soon, the Green Revolution also spread to middle farmers. At the time, this did manage to raise agricultural output and yields in certain crops (Siddiqui 1999); however, now some of the negative effects are more visible such as damage to soil, the level of the water table and the quality of water. But, overall, it did improve the incomes of certain sections of the rural population, which proved to be temporary relief.

The dirigiste economic strategy brought a very positive change in the industrial sector by building industries in key areas such as power generation, steel and manufacturing industries. However, it failed to achieve land reforms in the sense of curbing the rural power of the landlords and bringing socio-economic equality across the countryside. Despite a number of land reform measures, it did not break the social and economic power of the landlords and also failed to fully implement the "land to the tiller" policy. The rural poor did not experience any betterment as the majority of these sections also belonged to the lower castes. The government undertook 
measures to nationalise banks, which meant more credit was made available to the agricultural sector, and subsidies were also extended to agricultural inputs to support the "Green Revolution". These measures ultimately increased food production and reduced reliance on food imports. However, such a dirigiste strategy promoted capitalist development in agriculture and exposed certain inner contradictions, especially the fiscal crisis of the state. In the 1980s, government began to gradually liberalise trade so that by the mid-1980s India's current account deficit and external debt started to grow. Also, imports grew at a faster rate and the rising current account deficit became increasingly financed by commercial borrowing and non-resident Indian (NIR) remittances, which meant a greater dependence on foreign sources and at higher costs and short-term financing. And as a result, India's foreign debt sharply rose from USD 20.5 billion in 1980 to USD 72 billion in 1992, making India the world's third largest debtor after Brazil and Mexico (Nayyar 2017).

More such short relief came in the 1980s in the form of the availability of foreign funds for borrowing. Actually, extensive funds from oil exporting countries found their way into the Indian financial system. This private financial capital was now available for borrowing, and India took this opportunity and borrowed from commercial banks and non-resident Indians. Access to such capital allowed the government to increase its debt-financed investment. This came as a big relief for the government as the money was used to pay for imports that kept domestic inflation under control.

The government reliance on foreign borrowing provided short-term financial relief, and in the late-1980s easy access to international credit resulted in the rise of both public and foreign debt. Moreover, the Gulf War and the decline in remittances from Indian workers in that region, a dramatic rise in oil prices and, ultimately, the collapse of Soviet Union, created a very challenging situation for India. All these adverse domestic and international factors led to an increase in the current account deficit, which created fear among foreign lenders that India may not be able to meet its debt service obligations. As a result, the availability of foreign funds began to dry up, which led to a sharp reduction in reserves and, in July 1991, a balance of payments crisis.

\section{Economic Performance from 1991 to 2017}

India saw a severe balance of payments crisis in 1991, when it approached IMF for emergency loans. In return, the IMF demanded the implementation 
of neoliberal economic reforms involving trade liberalisation, a more favourable climate for foreign investors and also wide-ranging deregulation measures. The adoption of the "Structural Adjustment Programme" meant increased reliance on market forces and a new policy towards foreign capital. With the adoption of market-friendly policies towards foreign capital, the net inflows of capital rose from less than USD 1 billion in 1993 to USD 6 billion by 1999, which further rose from USD 15.7 billion in 2003 to USD 65 billion in 2014 (Chandrasekhar 2013). However, despite the government's efforts to attract foreign capital, India still received less FDI than other developing countries such as Mexico, Turkey and China, as shown in Figure 2.

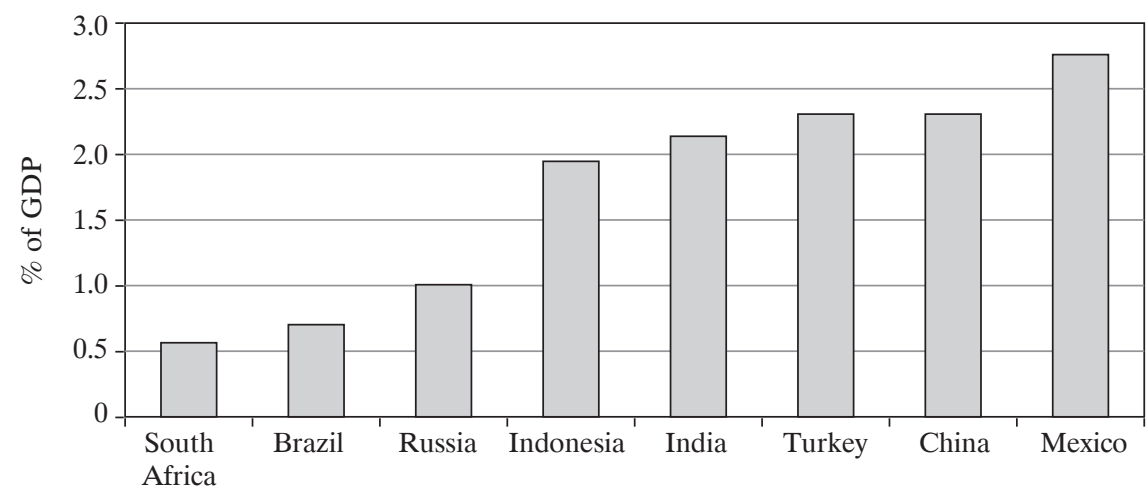

Fig. 2. FDI Net Inflows across Countries, 2016

Source: OECD (2017, p. 35), http://www.oecd.org/eco/surveys/economic-survey-india.htm (accessed: 15 January 2018).

The inflow of capital in such amounts would not have been possible without the relaxation in laws governing foreign capital and the removal of regulations regarding foreign shareholding and the liberalisation of rules governing foreign investments and the repatriation of profit and money from India (Siddiqui 2016a). The sharp increase in non-debt inflows of foreign capital, especially in portfolio and foreign direct investment, indicates a new trend. As Chandrasekhar (2013, p. 32) concluded: "India's relationship with foreign capital has shifted from muted hostility to one of attracting and winning its confidence, the nature of the regime of accumulation has changed as well. These changes had indeed taken India onto a high growth trajectory by activating mechanisms that were very different in the 1980s, 1990s and 2000s. The long period of relatively high growth created the impression that (...) the high growth was now irreversible. The argument 
seeks to establish that (...) the regimes of accumulation themselves were fragile, besides the fact that growth driven by dependence on financial flows is vulnerable because of the possibility that such inflows can stop, and capital outflows could occur, including for reasons unrelated to circumstances in the host country".

However, greater reliance on foreign capital pressurised India to implement fiscal reforms by bringing legislation in the form of the Fiscal Responsibility and Budgetary Management Act (FRBM), which was passed in 2003 to bring down the fiscal deficit to GDP ratio to $3 \%$. This was an attempt to restrain any attempt to raise growth based on debt-financed government spending (Patnaik 2016). In the post-2003 period, foreign capital inflows surged, triggering a credit boom that was largely available only to rich and upper-middle class consumers for housing loans, automobiles, and to government for infrastructure. This created optimism and spurred growth, but also increased vulnerability and potential defaulting. In recent years, soon after the boom began, non-performing assets in the banking system have risen sharply and banks profitability could currently be under threat.

It seems that the removal of restrictions on technology imports - so that foreign firms will find it more attractive to set up collaborative enterprises - would be likely to boost domestic production along with foreign capital, technology and management skills. Further capital liberalisation measures taken by the government provided opportunities for retail lending in Indian commercial banks' portfolios. Suddenly, the influx of foreign capital provided excessive liquidity in the system, which could be lent to consumers to allow the purchase of housing, automobiles and consumer durables. This credit was also extended without any collateral and on the basis of speculative projections of borrowers' current earning profiles. Such individuals have often borrowed excessive amounts of money from multiple sources without revealing this to creditors. The availability of external funds resulted in an increase in debt-finance demand in the late 1990s. As Chandrasekhar (2013, p. 20) argues: "[T]here was evidence of an incipient change in the regime of accumulation. There were two aspects to this change. The first was that private consumption expenditure on manufactured consumption goods and private investment in housing began to play a more important role (relative to public expenditure) in driving demand and growth. Second, associated with this, were signs that debt-financed private consumption expenditure was displacing debt-financed expenditure as a leading stimulus to growth". 


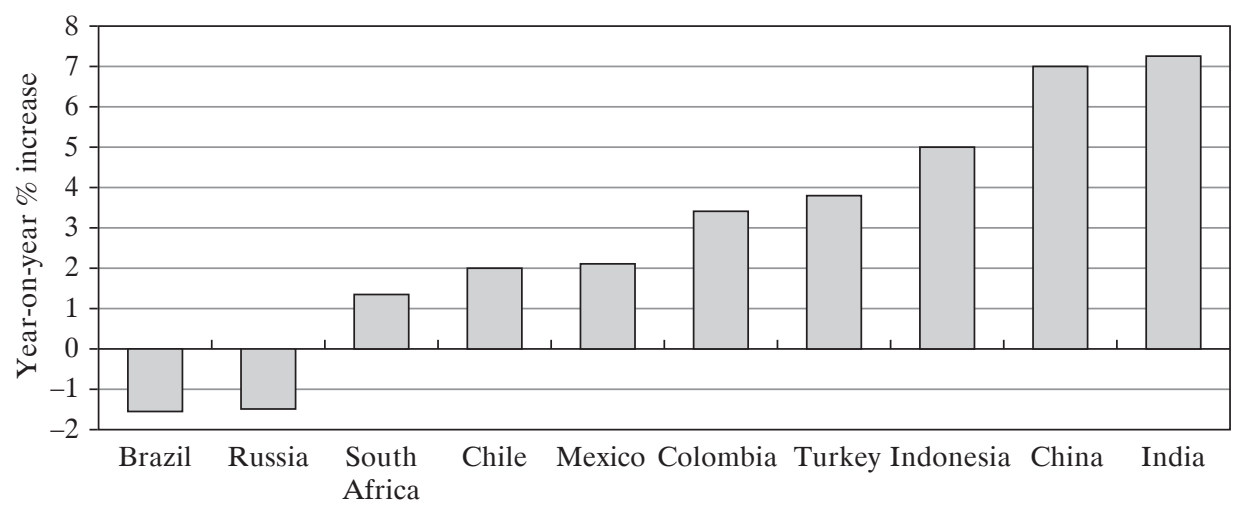

Fig. 3. Annual Average Growth Increase, 2015-16

Source: OECD (2017), http://www.oecd.org/eco/surveys/economic-survey-india.htm (accessed: 20 January 2018).

In 2015-16, India's growth performance was the highest in the world, slightly above China, as shown in Figure 3. However, only looking at overall growth does not give us the full picture; rather, we need to analyse sectoral growth later on in this article.

On the question of capital stock, during the pre-reform period the public sector was given the leading tasks of most capital-intensive projects such as irrigation canals, dams, electricity, steel mills, and so on. This accounted for a growing share of the country's capital stock. The public sector constituted $41 \%$ of the Indian economy's total capital stock in the 1980 . However, the public sector's share in India's domestic output has stagnated since the late 1980s. Indeed, its share in capital stock has declined since 1990 and employment has contracted by 10\% since the mid-1990s. As Nagaraj (2015, p. 42) argues, "The public sector's share in GDP (...) plummeted to $20 \%$ by 2008-09, an unprecedented decline of 5 percentage points in five years. However, as the boom went bust after the global financial crisis, the private corporate sector floundered, contracting investment demand, and affecting the banking sector with burgeoning bad debts (...). Thus, after more than two decades of economic reforms, in 2012-13, the public sector's share in GDP stood at 23\% (2 percentage points less than in 1991), employing 17 million workers (two million less than in 1991)".

There is no doubt that since the early 1990s industrial production has diversified with improvements in the quality of its products. However, the manufacturing sector's share has stagnated at about $15 \%$, while the 
industrial share has stagnated at around $26 \%$ of GDP after the reforms (Girdner \& Siddiqui 2008). When we look at the experiences in other countries, such as in East Asia and China, Indian industries have clearly not done very well. For instance, when we compare with China, both countries had roughly same levels of industrialisation in the 1950s; India, rather, at this time had slightly more developed industries than China, but by 2015 China became the world's second-largest manufacturing country (Siddiqui 2009), while India ranked tenth, producing one-quarter of China's industrial output (Nagaraj 2017). As Figure 4 indicates, in 2010, among the top manufacturing nations India was above Brazil, while China was second from top, just behind the US; over a period of only ten years, i.e., from 2000 to 2010, manufacturing declined in the US, but rose sharply in China, while India's manufacturing also increased but to much less of a degree than China (see Figure 4).

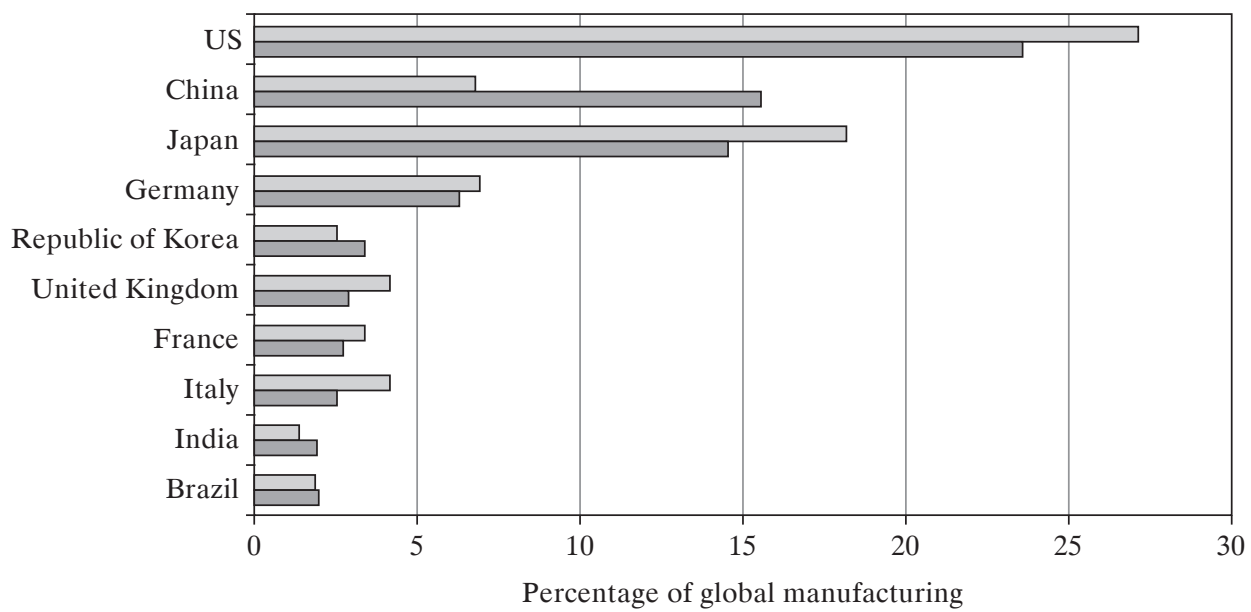

$\square 2000 \square 2010$

Fig. 4. World Top 10 Manufacturing Nations in 2000 and 2010 Source: UNIDO (2014).

On the subjects of post-liberal reforms and industrial performance, Nagaraj (2017, p. 63) summarises that: "the 25-year period can be subdivided into three distinct phases: 1992-96, 1997-2003 and 2003-14. The first phase represents the initial euphoria of reforms, with booming output and investment in the anticipation of a virtuous cycle of faster growth and exports. However, with the expectations of a boost in demand not being 
realised, industrial growth decelerated. It coincided with the Asian financial crisis, burst of the dot.com bubble, and freezing of credit markets in the US in the early 2000s. The period from 2003 to 2014 represents (...) the recent debt-led cycle of boom and bust (...). The turnaround in industrial domestic output growth rates [in 2014] are not supported by the trends in (i) credit growth and (ii) capacity utilisation in industry". Nagaraj further (2017, p. 67) notes: "the market-friendly policy framework constructed over the last quarter century has not served the manufacturing sector well, despite faster economic growth, and output diversification. The goal of rapid industrialising to catch up with the Asian peers, in an open trade and capital regime employing abundant labour for labour-intensive exports, did not materialise".

At present, the manufacturing sector contributes nearly $16 \%$ to India's GDP, provides jobs for $10 \%$ of the country's total workforce and produces nearly $80 \%$ of its total merchandise exports. Although the manufacturing sector is relatively small in comparison to India's whole economy, this sector could nevertheless play an important role in raising India's productivity and in its development efforts (Siddiqui 2014b).

In the light of a recent study by Dani Rodrik (2016), there is a need to revisit the question of industrialisation, which is still very important for creating employment, diversifying the economy and removing the low productivity workforce from agriculture. However, according to this study, the increased global integration and liberalisation has led to de-industrialisation in some regions. It is very important for a country like India to draw lessons from such a potentially adverse impact, which could be a huge destabilising factor in India. As Rodrik (2016, p. 2) argues: "With some exceptions, confined largely to [East] Asia, developing countries have experienced falling manufacturing shares in both employment and real value added, especially since the 1980 s. For the most part, these countries had built up modest manufacturing during the 1950s and 60s, behind protective walls and under policies of import substitution. These industries have been shrinking significantly since then. The low-income economies of sub-Saharan Africa have been affected nearly as much by these trends as the middle-income economies of Latin America - though there was less manufacturing to begin with in the former group of countries (...). Developing countries are turning into service economies without having gone through a proper experience of industrialisation. I call this premature deindustrialisation." Rodrik further narrates (2016, p. 2-3): "There are two senses in which the shrinking of manufacturing in low and medium 
economies can be viewed as premature. The first, purely descriptive, sense is that these economies are undergoing deindustrialisation much earlier than the historical norms (...). The second sense in which this is premature is that early deindustrialisation may have detrimental effects on economic growth. Manufacturing activities have some features that make them instrumental in the process of growth".

Table 2. India's Macroeconomic Indicators and Projections (Annual \% Changes) from 2013-14 to 2018-19

\begin{tabular}{l|c|c|c|c|c|c}
\hline \multicolumn{1}{c|}{ Specification } & $2013-14$ & $2014-15$ & $2015-16$ & $2016-17$ & $2017-18^{\mathrm{b}}$ & $2018-19^{\mathrm{b}}$ \\
\hline Real GDP & 6.6 & 7.2 & 7.6 & 7.0 & 7.3 & 7.7 \\
\hline Consumer Price Index (CPI) & 9.4 & 5.8 & 4.9 & 4.8 & 5.0 & 4.6 \\
\hline $\begin{array}{l}\text { Wholesale Price Index } \\
\text { (WPI) }\end{array}$ & 6.0 & 2.0 & -2.5 & 2.8 & 4.0 & 4.2 \\
\hline Fiscal Balance (\% of GDP) & -6.7 & -6.5 & -7.2 & -7.0 & -6.7 & -6.4 \\
\hline $\begin{array}{l}\text { Current Account Balance } \\
\text { (\% of GDP) }\end{array}$ & -1.7 & -1.3 & -1.1 & -0.8 & -0.9 & -0.9 \\
\hline $\begin{array}{l}\text { Gross Fixed Capital } \\
\text { Formation }\end{array}$ & 3.4 & 4.9 & 3.9 & 0.4 & 4.3 & 7.3 \\
\hline $\begin{array}{l}\text { Total Domestic Expenditure } \\
\text { Exports of Goods and }\end{array}$ & 2.0 & 6.9 & 8.0 & 5.4 & 7.5 & 7.9 \\
$\begin{array}{l}\text { Services, National Accounts } \\
\text { Basis }\end{array}$ & 7.8 & 1.7 & -5.2 & 4.5 & 4.6 & 5.2 \\
$\begin{array}{l}\text { Imports of Goods and } \\
\text { Services, National Accounts } \\
\text { Basis }\end{array}$ & -8.2 & 0.8 & -2.8 & -2.3 & 5.4 & 6.3 \\
\hline $\begin{array}{l}\text { Net Exports, Contribution to } \\
\text { Growth of Real GDP }\end{array}$ & 4.5 & 0.2 & -0.5 & 1.5 & -0.2 & -0.2 \\
\hline
\end{tabular}

${ }^{a}$ GDP measured in market prices (i.e. at factor costs plus indirect taxes, minus subsidies), b estimated.

Source: OECD (2017, p. 12), http://www.oecd.org/eco/surveys/economic-survey-india.htm (accessed: 6 January 2018).

Table 2 shows India's macroeconomic changes (average annual \% changes) from 2013-14 to 2018-19. The figures for 2017-18 and 2018-19 are projected data from the OECD. India's rates are projected to remain above $7 \%$ per annum, while the consumer price index is expected to remain low. Also, imports will remain higher than exports (see Table 2).

The share of agriculture in terms of GDP in 1950-51 was $56.7 \%$, while its share in total employment was $85 \%$ for the same period. The share of 
agriculture in GDP fell sharply thereafter, and by $2014-15$ it was $13 \%$, while the fall in the share in agricultural employment was much slower (55\%), and more than half the population still depends on agriculture for their livelihood, as shown in Table 3.

Table 3. Share of Agriculture in GDP and Employment in India

\begin{tabular}{c|c|c}
\hline Year & $\begin{array}{c}\text { Share of Agriculture in GDP } \\
\text { at 1999-2000 Prices (\%) }\end{array}$ & $\begin{array}{c}\text { Share of Agriculture } \\
\text { in Employment (\%) }\end{array}$ \\
\hline $1950-51$ & 56.70 & 85.0 \\
\hline $1960-61$ & 52.48 & 77.3 \\
\hline $1970-71$ & 46.00 & 63.9 \\
\hline $1980-81$ & 40.00 & 60.0 \\
\hline $1991-92$ & 34.04 & 58.1 \\
\hline $2001-02$ & 25.18 & 57.3 \\
\hline $2011-12$ & 14.00 & 56.0 \\
\hline $2015-16$ & 13.05 & 55.0 \\
\hline
\end{tabular}

Source: National Sample Survey (1950-2018).

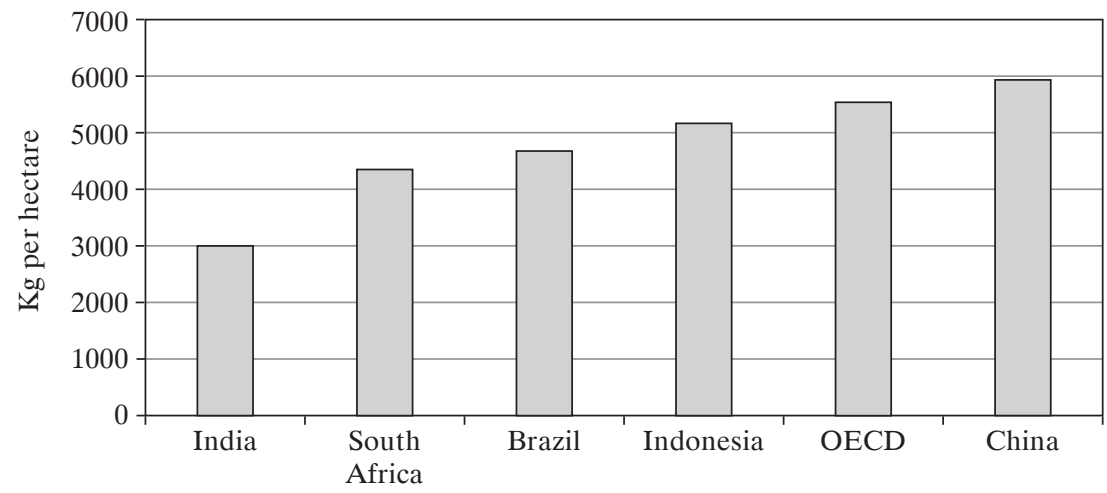

Fig. 5. Productivity in the Agriculture Sector: Cereal Yield, 2015

Source: OECD (2017, p. 48), http://www.oecd.org/eco/surveys/economic-survey-india.htm (accessed: 4 January 2018).

Although India's annual growth rate was the highest in the world in 2016, when we look at productivity in agriculture, this is quite low for India and nearly half that of China, as indicated in Figure 5. India's productivity in the agricultural sector is less than in other developing countries such as Indonesia, South Africa and Brazil. 
During the neoliberal reforms, the agriculture sector had been completely ignored, despite nearly two-thirds of the population relying on it for employment and income. Also, the majority of India's poor live in rural areas, and rely heavily on the performance of the agricultural sector. The 1991 economic reforms package did not consider specific policy regarding agriculture, especially in terms of helping small and medium farmers. Moreover, it was presumed that freeing the agricultural markets and liberalising external trade in agricultural commodities would provide price incentives, leading to a rapid increase in the incomes of farmers and investment in agriculture. With the greater role of market forces leading to a sharp decline in the availability of institutional credit, subsides on fertiliser and electricity were also reduced drastically. All these developments increased difficulties for small and marginal farmers, who were forced into greater reliance on informal credit from money lenders and input from suppliers cum merchants.

There has been little increase in income and productivity for the people trapped in the agricultural and informal sectors, which continue to employ around $90 \%$ of India's entire workforce. Agricultural stagnation, poverty, and sectarian and religious conflicts have caused social instability and political division, which may well plague India in the future (Siddiqui 2017a). In order to achieve sustainable growth in the future, India has to radically change the direction of its economic strategy towards domestic wage-led growth and employment creation, and also employment diversification to shift workers away from the low-productivity agricultural sector to activities with higher productivity and value added in manufacturing.

Since the introduction of the reforms, the government's priority has changed from self-sufficiency in food production and consumption to production for export. Under the WTO (World Trade Organisation), further adoption of trade liberalisation led to the removal of restrictions on exports for certain agricultural goods, particularly rice and wheat; import tariffs were also removed from a number of agricultural commodities. India becoming party to the WTO raised hopes that farmers would benefit from access to global markets. India agreed to zero tariffs on a wide range of crops; however, global uncertainties in prices and the nature of competition were ignored. Indian farmers operated in highly uncertain and volatile global markets, competing against highly subsidised and capital-intensive agribusiness in developed countries. When global prices fell between 1996 and 2002, the adverse impact of imports was realised and India was forced to renegotiate with the WTO (Siddiqui 2016a). 
However, neoliberal reforms overlooked the agriculture sector, which was a deliberate policy as government was keen to resolve the balance of payments crisis but seemed to have no long-term strategy. This decision was difficult to understand as about two-thirds of the workforce and more than three-quarters of the poor in rural areas were directly or indirectly employed in the agriculture sector in the Indian economy. The economic reforms did not take into consideration this very important sector.

In the early 2000s, the rise of demand for IT services abroad created an IT services boom as profits in this sector rose, providing opportunities for further foreign capital investment collaboration in this sector. This period also coincided with India beginning to be seen as a favoured destination for foreign financial investors. This was also a period when Indian businesses went for excessive borrowing from foreign securities. Moreover, in the 2010s, capital inflows exceeded the balance of payments, leading to an appreciation of the Indian currency. In fact, excessive foreign capital inflows have resulted in surplus foreign exchange reserves, though it is important to note that these reserves are not earned through exports but are rather borrowed from foreign capital investors.

With its increased integration with the global market, the Indian information technology (IT) industry has grown phenomenally. With increased demand for software following the personal computer (PC) revolution of the 1980s, Indian IT companies have responded to the growing demand for networking. The commercialisation of the internet in the 1990s and growing demands for IT engineers from India to repair and maintain computers prompted the rapid growth of the IT industry. After the economic reforms of 1991, as observed by Das and Sagara (2017, p. 57), "India's position as the preferred business process outsourcing (BPO) and knowledge process outsourcing (KPO) destination in the world had been established. India entered the global IT market by capitalising on the demand for low-cost but high-quality programming skills (...). Besides a favourable domestic policy climate and highly attractive export promotion schemes, a host of external factors was crucial for the growth of the software industry". Analysing the impressive performance of Indian IT services in recent years, Das and Sagara (2017, p. 57) further note that: "in 2005 alone, IT and BPO/BPM had generated revenue worth USD 148 billion (amounting to $8.1 \%$ of GDP), and its exports had amounted to approximately USD 98 billion. The Indian IT companies have set up to over 600 delivery centres across 78 countries, thus maintaining their leadership position in the global sourcing arena (...) the 
Indian IT sector is still viewed by the major MNCs from the industrialised nations as a destination where cheap labour is available".

The important question is whether the rapid economic growth was actually due to the economic liberalisation policy of the 1991, to which it is often attributed. To answer this, Nayyar (2017, p. 45) states: "If we consider the $20^{\text {th }}$ century in its entirety, the turning point in economic performance, or the structural break in economic growth, is 1951-52. If we consider the period 1950-1951 to 2000-01, the turning point in economic growth is $1980-81$ (...). During the $20^{\text {th }}$ century, the most significant structural break, or departure from the long-term trend in economic growth, was 1951-52, followed by 1980-81. In either case, 1991 was not a turning point (...)". He further (2017, p. 46) notes: "The biggest failure of the last 25 years is that, despite such rapid economic growth, employment creation has simply not been commensurate. In fact, the employment elasticity of output declined steadily from reasonably high levels during 1972-73 to 1983 (0.60) through modest levels during 1983 to 1993-94 (0.41), to low levels during 1993-94 to 2004-05 (0.17) and 2004-05 to 2011-12 (0.04). In fact, between 2004-05 and 2011-12, employment elasticity of output in agriculture $(-0.42)$ and in manufacturing (0.13) plummeted, as compared to the 1983 to 1993-94 period when in was much higher in both agriculture (0.49) and manufacturing (0.47)".

\section{Concluding Remarks}

India and China were the top two manufacturing nations worldwide until the British conquest of Bengal and the defeat of the Chinese in the first opium war. In fact, colonialism degraded the Indian economy and squeezed the incentives for local investment in industry and agriculture. For the majority of the colonial period, Indian agriculture stagnated and foodgrain output fell. As a result, peasants became highly indebted to money lenders and had hardly any support from public expenditure on irrigation, soil management or rural infrastructure, particularly devastating when the agricultural sector experienced crop failure and drought. The primary goal for the British colonial administration was to extract revenues from the peasantry. From the mid-18th century, India's economy was integrated into the British colonial system which, besides extracting surplus value, also imposed an international division of labour with unequal terms of trade where India was turned into a supplier of primary commodities. 
During the colonial period, the Indian economy became subservient rather than sovereign in terms of policy matters. The Indian economic surplus was transferred to Britain, which did not lead to job creation in the local economy. As a result, economic development was hampered by the removal of "surplus", along with very high land rents and tribute charges. A densely populated country like India was drawn into the orbit of exploitation in the mid-18th century and, later on, into the interest of British industry. Such development created mass poverty, de-industrialisation, starvation and famine across the entirety of India.

The study found that soon after independence in 1947, the Indian government took a number of initiatives to enhance industrial and agricultural development. Initially, these met with some modest success, including building key industries, becoming self-sufficient in terms of food production and improving literacy rates. However, the biggest failure was that it did not make any real impression on the country's huge unemployment problems. By the mid-1960s economic growth had begun to falter and the fiscal crisis of the state deepened. Finally, India sought an IMF loan in 1991 to avert a balance of payments crisis. In return, India was asked to adopt neoliberal reforms.

To compare Indian economic policies under neoliberal reforms with those of the previous period under dirigisme would seem to be important, particularly when we consider this comparison in terms of employment expansion. In the period of neoliberal reform, growth rates accelerated to $7 \%$ annually, but the rate of growth of employment has remained at only $1 \%$, while in the dirigiste period the average growth rate was $3.5 \%$, but the expansion of employment was doubled i.e. $2 \%$ annually. It seems that the rate of employment growth was far below the natural growth rate of the workforce. This is greater when we further consider displaced peasants and petty producers due to the accelerated process of "primitive accumulation" unleashed by the economic reforms. The neoliberal reform, rather than creating new jobs, saw the total number of unemployed rise and the steady growth of the relative size of the labour reserve.

In fact, in the late 1950s and 1960s the industrial sector did witness a sharp rise. For example, the share of manufacturing in GDP rose from $9 \%$ in 1951 to $16 \%$ in 1961 . Indeed, a decade later this share reached $18 \%$ before reaching its peak of $20 \%$ in 1996 . However, the industrial share in GDP was still less in comparison to other developing economies, particularly in East Asia. For example, in 1971, the manufacturing share in GDP for South 
Korea was 25\%, Malaysia 28\%, Thailand 26\%, China 35\% and Brazil 29\% (Siddiqui 2017b).

The Indian growth story is one of around 4\% per annum from the 1950s through to 1981, and then 6.3\% from 1982 to 2016 (Nayyar 2017). The source of recent high growth appears to be rooted in services such as real estate, construction, automobiles, IT industries, commercial centres, and the financial sector. Many of these new developments are taking place around urban and semi-urban centres. By contrast, India's rural economy has experienced very slow growth and, indeed, near stagnation during the pro-market reform period (Dreze \& Sen 2013). The study has argued that India's progress towards industrialisation has been disappointing and the optimism that foreign capital and technology would bring efficiency and boost growth in manufacturing has largely been proven unfounded.

Since neoliberal reforms were undertaken in 1991, the agriculture sector hardly saw any benefits and, during this period, its growth rates were negligible (Siddiqui 2010). The pursuit of neoliberal economic policies has led to the withdrawal of the state in assisting farmers in particular and the rural sector in general, and instead the state is promoting the interests of global financial capital, with which Indian corporate capital is closely integrated. Despite the fact that the majority of the country's population has not witnessed any improvement in its living conditions, the government nevertheless celebrates this as a "great achievement"; it has completely ignored economists such as John Stuart Mill, who said that he did not mind a zero growth rate if workers were better off in such a stationary state than in a growing economy. For him, improvements in workers' real incomes should take priority over high GDP growth rates.

It seems that recent growth based on neoliberal economic policies is fragile as their success relies heavily on foreign capital inflows (Siddiqui 1998); if such inflows reverse for external reasons or due to the global situation, then this could lead to a similar situation as that experienced during the 1997 East Asian crisis.

Now, after more than a quarter of a century since the inception of the neoliberal market reforms, it seems that the high growth rate has failed to make any impression on the expansion of employment. Therefore, the study argues that the problems lie not just in rapid growth rates, but in the reliance on unsustainable stimuli to growth. The current growth is not sustainable as it is unable to address the problems of mass unemployment and other forms of social deprivation in India. 
India faces many challenges of poverty and growing inequality. It needs to stimulate growth within its manufacturing sector rather than increase its dependence on export-led growth, as such a strategy relies on foreign demands and markets which are already stagnant and for which there is little hope of a dramatic reversal. The study suggests that an alternative economic policy is needed, which should be based on raising the incomes of agricultural workers, expanding domestic markets, and the revival of public investment in crucial areas such as irrigation, education and health. Such measures would eliminate illiteracy and improve health and would raise productivity and domestic markets. Therefore, government intervention is needed to achieve inclusive growth; such intervention should be aimed at increasing employment and redistributing incomes, and ultimately ensuring access to basic services such as food, education and healthcare.

\section{Bibliography}

Bagchi, A. K. (2010) Colonialism and Indian Economy. UK: Oxford University Press.

Chandrasekhar, C. P. (2013) "Fragile Foundation: Foreign Capital and Growth after Liberalisation". Social Scientist 41(1/2): 17-33.

Das, K. and Sagara, H. (2017) "State and the IT Industry in India: An Overview". Economic and Political Weekly LII (41): 56-64.

Das Gupta, C. (2016) State and Capital in Independent India: Institutions and Accumulation. Cambridge: Cambridge University Press.

Dreze, J. and Sen, A. (2013) An Uncertain Glory: India and Its Contradictions. London: Allen Lane.

Girdner, E. J. and Siddiqui, K. (2008) "Neoliberal Globalization, Poverty Creation and Environmental Degradation in Developing Countries". International Journal of Environment and Development 5(1): 1-27.

IMF (2017) "World Economic Outlook, October", https:/uk.ask.com/youtube?q=imf+ world+economic +outlook\&v=voJJrEKQL2Y (accessed: 5 January 2018).

Maddison, A. (2003) The World Economy: Historical Statistics. Paris: OECD.

Ministry of Finance (1991-92) "Budget Speech 1991-92", 24 July, New Delhi, http:// indiabudget.nic.in/bspeech/bs199192.pdf (accessed: 5 June 2016).

Nagaraj, R. (2015) "Can the Public Sector Revive the Economy? Review of the Evidence and a Policy Suggestion". Economic and Political Weekly L(5): 41-46, 31 January.

Nagaraj, R. (2017) "Economic Reforms and Manufacturing Sector Growth: Need for Reconfiguring the Industrialisation Model". Economic and Political Weekly LII(2): 61-68, 14 January.

National Sample Survey (1950-2018) Central Statistical Organisation, Government of India, New Delhi.

Nayyar, D. (2017) "Economic Liberalisation in India: Then and Now". Economic and Political Weekly 52(2): 41-48. 
OECD (2017) “OECD Economic Survey: India”, February. Paris: OECD, http://www. oecd.org/eco/surveys/INDIA-2017-OECD-economic-survey-overview.pdf (accessed: 6 January 2018).

Patnaik, P. (2014) "Imperialism and the Agrarian Question". Agrarian South: Journal of Political Economy 3(1): 1-15, https://doi.org/10.1177/2277976014530229.

Patnaik, P. (2016) “Capitalism and India's Democratic Revolution”. Social Scientist 44 (1/2): 3-15.

Rodrik, D. (2016) "Premature Deindustrialization". Journal of Economic Growth 21: 1-33, https://doi.org/10.1007/s10887-015-9122-3.

Sen, A. (1981) Poverty Famines: An Essay on Entitlement and Deprivation. New York: Oxford University Press.

Siddiqui, K. (1990) "Historical Roots of Mass Poverty in India" in C. A. Thayer, J. Camilleri, and K. Siddiqui (eds) Trends and Strains. New Delhi: Peoples Publishing House.

Siddiqui, K. (1996) "Growth of Modern Industries under Colonial Regime: Industrial Development in British India between 1900 and 1946". Pakistan Journal of History and Culture 17(1): 11-59, January.

Siddiqui, K. (1998) "The Export of Agricultural Commodities, Poverty and Ecological Crisis: A Case Study of Central American Countries". Economic and Political Weekly 33(39): A128-A137, 26 September.

Siddiqui, K. (1999) "New Technology and Process of Differentiation: Two Sugarcane Cultivating Villages in UP, India". Economic and Political Weekly 34(52): A39-A53, 25 December.

Siddiqui, K. (2009) "The Political Economy of Growth in China and India”. Journal of Asian Public Policy 1(2): 17-35, https://doi.org/10.1080/17516230902734528.

Siddiqui, K. (2010) "Globalisation and Neo-liberal Economic Reforms in India: A Critical Review" in S. K. Pramanick and R. Ganguly (eds) Globalization in India: New Frontiers and Emerging Challenges. New Delhi: Prentice Hall.

Siddiqui, K. (2012) "Developing Countries Experience with Neoliberalism and Globalisation". Research in Applied Economics 4(4): 12-37, https://doi.org/10.5296/ rae.v4i4.2878.

Siddiqui, K. (2014a) "Contradictions in Development: Growth and Crisis in Indian Economy". Economic and Regional Studies 7(3): 82-98.

Siddiqui, K. (2014b) "Growth and Crisis in India's Political Economy from 1991 to 2013". International Journal of Social and Economic Research 4(2): 84-99, April-June.

Siddiqui, K. (2015) "Challenges for Industrialisation in India: State versus Market Policies". Research in World Economy 6(2): 85-98, https://doi.org/10.5430/rwe. v6n2p85.

Siddiqui, K. (2016a) "International Trade, WTO and Economic Development". World Review of Political Economy 7(4): 424-50.

Siddiqui, K. (2016b) "Will the Growth of the BRICs Cause a Shift in the Global Balance of Economic Power in the 21st Century?". International Journal of Political Economy 45(4): 315-38, https://doi.org/10.1080/08911916.2016.1270084.

Siddiqui, K. (2017a) "Hindutva, Neoliberalism and the Reinventing of India". Journal of Economic and Social Thought 4(2): 142-86.

Siddiqui, K. (2017b) "Capital Liberalization and Economic Instability". Journal of Economics and Political Economy 4(1): 659-77. 
Siddiqui, K. (2018) “The Political Economy of India's Post-planning Economic Reform: A Critical Review". World Review of Political Economy 9(2): 235-264, https://doi. org/10.13169/worlrevipoliecon.9.2.0235.

Srivastava, R. (2012) "Changing Employment Conditions of Indian Workforce and Implications for Decent Work". Global Labour Journal 3(1): 63-90, https://doi. org/10.15173/glj.v3i1.1113.

Sunderland, J. T. (1929) India in Bondage; Her Right to Freedom and a Place among the Great Nations. New York: Lewis Copeland.

Tharoor, S. (2017) Inglorious Empire: What the British Did to India. London: Penguin Books.

UNIDO (2014) “International Yearbook of Industrial Statistics". Vienna, https://www. unido.org/resources/publications/flagship-publications/annualreport/annual-report2014 (accessed: 5 March 2018).

World Bank (2016) "Dancing with the Giants: China, India, and the Global Economy". World Bank Report. Washington DC: World Bank, https://openknowledge.worldbank. org/handle/10986/6632 (accessed: 10 July 2017).

\section{Abstract}

(przekład: Agnieszka Wałęga i Grzegorz Wałęga)

\section{Ekonomia polityczna a zmiany gospodarcze w Indiach w ostatnim stuleciu}

Celem opracowania jest ocena transformacji Indii kolonialnych w nowoczesną gospodarkę w ostatnim stuleciu na podstawie zmian wskaźników makroekonomicznych. Kwestia ta jest o tyle ważna, że pomaga zrozumieć w szerszym kontekście związki pomiędzy wzrostem gospodarczym i wynikającymi z niego zmianami sektorowymi oraz dotyczącymi zatrudnienia w krajach rozwijających się, takich jak Indie. Zastosowana metodologia badań wynika z przyjętych celów badawczych i uwzględnia międzynarodowe statystyki, zapewniające narzędzia do realizacji celów i udzielenia odpowiedzi na postawione pytania badawcze. W opracowaniu wykazano, że w okresie kolonialnym politykę ekonomiczną Indii bardziej określały związki polityczne z Wielką Brytanią, aniżeli prowadzono ją w sposób samodzielny. W konsekwencji rozwój gospodarczy kraju był utrudniony przez odpływ nadwyżek zasobów ekonomicznych do metropolii oraz stosowanie bardzo wysokich opłat i danin. Indie, jako gęsto zaludniony kraj, został wciągnięty w orbitę wyzysku ekonomicznego w połowie XVIII wieku. Wkrótce po odzyskaniu niepodległości w 1947 r. rząd Indii podjął szereg inicjatyw mających na celu rozwój przemysłu i rolnictwa, jednak ich największym niepowodzeniem było to, że nie wywarły one rzeczywistego wpływu na ogromne problemy z bezrobociem.

Słowa kluczowe: gospodarka indyjska, okres kolonialny, głód, wskaźniki wzrostu gospodarczego i reformy neoliberalne. 